CLINICAL STUDY

\title{
Function of regulatory T-cells improved by dexamethasone in Graves' disease
}

\author{
Yun $\mathrm{Hu}^{1}$, Wei Tian ${ }^{2}$, Ling-Ling Zhang ${ }^{1}$, Hao $\mathrm{Liu}^{1}$, Guo-Ping Yin $^{1}$, Bang-Shun He ${ }^{3}$ and Xiao-Ming Mao ${ }^{1}$ \\ ${ }^{1}$ Department of Endocrinology, ${ }^{2}$ Department of Rehabilitation and ${ }^{3}$ Central Laboratory, Nanjing First Hospital Affiliated to Nanjing Medical University, \\ 68 Changle Street, Nanjing 210006, China \\ (Correspondence should be addressed to X-M Mao; Email: maoxming@163.com)
}

\begin{abstract}
Objective: Intrathyroid injection of dexamethasone (DEX) has been used to treat Graves' disease (GD); however, the mechanism of this treatment remains poorly understood. The objective of this study was to investigate the effects of DEX on the function of regulatory $\mathrm{T}$ (Treg) cells $\left(\mathrm{CD} 4{ }^{+} \mathrm{CD} 25^{+} \mathrm{T}\right.$ cells) in patients with GD.

Methods: Peripheral blood was obtained from 20 patients with GD, and peripheral blood mononuclear cells (PBMCs) were isolated by Ficoll-Hypaque density gradient separation. CD $4{ }^{+} \mathrm{CD} 25^{-} / \mathrm{CD} 4^{+}$ $\mathrm{CD} 25^{+} \mathrm{T}$ cells were isolated by immunomagnetic selection and DEX was co-cultured with PBMCs or isolated T-cells for $72 \mathrm{~h}$. Treg cell function was analyzed using the proliferation rate of $\mathrm{CD} 4^{+}$ CD25 T cells.

Results: The proportion of Treg cells and the transcription factor forkhead box P3 (FOXP3) mRNA expression in PBMCs decreased in GD patients compared with healthy subjects, and Treg cell function was impaired in patients with GD. Although the proportion of Treg cells and FOXP 3 mRNA expression in PBMCs did not increase, the function of Treg cells improved after the treatment with DEX. Moreover, the proportion of T-helper 2 (Th2) cells was decreased by the DEX treatment.

Conclusions: DEX could effectively improve the function of Treg cells and set up a new balance of Th1/Th2 in GD patients. This study might help to further understand the immune mechanism of the intrathyroid injection of DEX in the treatment of GD and facilitate the potential use of this therapy.
\end{abstract}

European Journal of Endocrinology 166 641-646

\section{Introduction}

Graves' disease (GD), the leading cause of hyperthyroidism and thyroid eye disease, is one of the most common organ-specific autoimmune diseases and is manifested with diffuse goiter, hyperthyroidism, and thyroidspecific autoantibodies with/without ophthalmopathy and/or dermopathy. However, the exact pathogenesis of GD remains poorly understood.

The recent breakthrough discovery of regulatory $\mathrm{T}$ (Treg) cells has shed light on its roles in developing and progressing GD. Depletion of Treg cells rendered some C57BL/6 mice susceptible to induction of GD $(1,2)$. In untreated GD patients, the percentage of circulating $\mathrm{CD} 4{ }^{+} \mathrm{CD} 25^{+} \mathrm{FOXP}^{+}$Treg cells markedly decreased (3). Moreover, Treg cells play an important role in the link between GD and Hashimoto's thyroiditis (4).

Treg cells, a subset of $\mathrm{CD} 4^{+} \mathrm{T}$ cells, expressed high levels of $\mathrm{CD} 25$ and the transcription factor forkhead box P3 (FOXP3), and thus play an important role in the prevention of autoimmune disease and exert a key homeostatic effect in T-helper (Th) cells (5). Th cells consist of two subpopulations, Th1 and Th2, based on distinctive patterns of cytokine production (6).
Th1 cells, which secrete interferon $\gamma($ IFN $\gamma)$, interleukin 2 (IL2), and IL12, are associated strongly with cellmediated immune responses, while Th2 cells, which secrete IL4, IL5, and IL10, are involved in humoral immunity (7). The imbalance of Th1/Th2 cells caused by Treg cell dysfunction may determine the outcome of autoimmune diseases (8). Although GD is considered an autoantibody-mediated Th2-dominant disease, Th1 dominance may prevail in its initial phase (9).

Antithyroid drugs are the main treatment strategy for GD in China and Europe, and a long-term therapy of about 12-18 months is usually adopted $(10,11)$, requiring careful monitoring of patients for side effects of rash, joint pain, liver inflammation, and agranulocytosis $(11,12)$. After therapy withdrawal, the relapse rate is very high $(40-60 \%)$, and many patients need further treatment.

In our previous study, a new treatment strategy for GD was introduced (13). After methimazole (18 months) was combined with an intrathyroid injection of dexamethasone (DEX; 3 months), the relapse rate of hyperthyroidism was markedly reduced compared with methimazole alone ( 7.4 vs $51 \%$ ) during the 2-year follow-up period, and serum thyrotropin receptor 
antibody (TR-Ab) levels, the TR-Ab positive rate, and thyroid volume also decreased (13). However, the mechanism by which DEX reduces the relapse rate of GD is not fully understood.

DEX is a kind of glucocorticoid usually used in the treatment of Graves' ophthalmopathy (GO) and is one of the most effective medicines $(14,15)$. Some reports showed that Treg cell count increased with DEX treatment in chronic idiopathic thrombocytopenic purpura and other autoimmune diseases $(16,17)$.

In this study, we isolated $\mathrm{CD} 4{ }^{+} \mathrm{CD} 25^{-} / \mathrm{CD} 4^{+} \mathrm{CD} 25^{+} \mathrm{T}$ cells from the peripheral blood of untreated GD patients and evaluated the effects of DEX, cyclophosphamide (CTX), and azathioprine (AZA) on Treg cell function. We found that DEX can improve Treg cell function in GD patients. Thus, the reduction in the relapse rate of hyperthyroidism with DEX treatment might relate to its modulation of Treg cells in GD patients.

\section{Patients and methods}

\section{Patients}

Peripheral blood was obtained from 20 newly diagnosed patients with GD. None of the patients had overt GO nor received any antithyroid treatment. Diagnosis of GD was established in accordance with commonly accepted clinical and laboratory criteria: hyperthyroidism; diffuse goiter without nodular formation at ultrasound; uniform pattern of uptake on scan with Tc-99m; and the presence of TR-Ab in the serum. The diagnosis of hyperthyroidism was based on signs and symptoms of thyrotoxicosis and on the basis of raised free thyroxine $\left(\mathrm{FT}_{4}\right)$ levels with low TSH levels. Peripheral blood was also obtained from 18 healthy individuals with normal TSH and $\mathrm{FT}_{4}$ and negative TR-Ab in the serum. Patients with other coexistent endocrine or organ-specific autoimmune disease, such as those with atopic dermatitis or bronchial asthma, were excluded from the study. Patients taking medications (such as corticosteroids) that could affect the immune system were also excluded. The clinical characteristics of patients with GD and healthy controls are shown in Table 1. Written informed consent was obtained from

Table 1 Clinical characteristics of GD patients.

\begin{tabular}{llll}
\hline & $\begin{array}{l}\text { Healthy } \\
\text { controls }\end{array}$ & GD patients & $\boldsymbol{P}$ value \\
\hline$n$ & 18 & 20 & \\
Age & $34.55 \pm 1.45$ & $32.25 \pm 2.49$ & $>0.05$ \\
Gender $(\%$ of female) & 77.8 & 75.0 & $>0.05$ \\
$\mathrm{TSH}(\mu \mathrm{lU} / \mathrm{ml})$ & $2.21 \pm 0.28$ & $0.02 \pm 0.01$ & $<0.05$ \\
$\mathrm{FT}_{3}(\mathrm{pg} / \mathrm{ml})$ & $3.11 \pm 0.08$ & $10.25 \pm 1.26$ & $<0.05$ \\
$\mathrm{FT}_{4}(\mathrm{ng} / \mathrm{dl})$ & $0.90 \pm 0.04$ & $3.04 \pm 0.29$ & $<0.05$ \\
$\mathrm{TR}-\mathrm{Ab}(\mathrm{U} / \mathrm{l})$ & $5.07 \pm 0.81$ & $91.41 \pm 22.62$ & $<0.05$ \\
$\mathrm{TG}-\mathrm{Ab}(\mathrm{IU} / \mathrm{ml})$ & $1.97 \pm 0.27$ & $252.79 \pm 56.53$ & $<0.05$ \\
$\mathrm{TPO}-\mathrm{Ab}(\mathrm{IU} / \mathrm{ml})$ & $1.47 \pm 0.34$ & $424.24 \pm 95.27$ & $<0.05$ \\
\hline
\end{tabular}

the subjects before the study, ethics permission was obtained for the use of all samples, and the study was approved by the Local Ethics Committee of our hospital.

\section{T-cell isolation and expansion}

Peripheral blood mononuclear cells (PBMCs) were isolated from heparinized blood by Ficoll-Hypaque density gradient separation. $\mathrm{CD} 4^{+} \mathrm{CD} 25^{-} / \mathrm{CD} 4^{+}$ $\mathrm{CD} 25^{+} \mathrm{T}$ cells were isolated from PBMCs by immunomagnetic selection using the Treg isolation kit (Miltenyi Biotec, Bergisch Gladbach, Germany) (18). Cell purity was always $>95 \%$, as assessed by flow cytometry analysis.

The isolated PBMCs and T-cells were cultured in RPMI-1640 medium (10\% fetal bovine serum, Gibco Life Technologies) for $72 \mathrm{~h}$ in vitro, and T-cell proliferation was stimulated with $100 \mathrm{ng} / \mathrm{ml}$ each of anti-CD3 and anti-CD28 MABs (eBioscience, Inc., San Diego, CA, USA).

\section{Methylthiazol tetrazolium assay}

Methylthiazol tetrazolium (MTT) assay was used to determine the terminal concentrations of the immunosuppressive agents. PBMCs were seeded at a density of $1 \times 10^{4}$ cells/well in 96-well plates in $200 \mu \mathrm{l}$ volume media. DEX, CTX, and AZA were added in different doses $\left(10^{-3}, 10^{-4}, 10^{-5}\right.$, and $\left.10^{-6} \mathrm{mmol} / \mathrm{l}\right)$. The PBMCs were cultured for $72 \mathrm{~h}$ and then $10 \mu \mathrm{l}$ of MTT solution ( $5 \mathrm{mg} / \mathrm{ml}$ in PBS) was added into each well. The cells were incubated at $37^{\circ} \mathrm{C}$ for $4 \mathrm{~h}$ allowing the MTT to be metabolized. The supernatant was removed after centrifugation and $100 \mu \mathrm{l}$ DMSO was added into each well to dissolve formazan crystals. The absorbance of the solutions with dye was measured at $492 \mathrm{~nm}$ on a multiwell spectrophotometer (BioTek, Winooski, VT, USA).

\section{Flow cytometry analysis}

PBMCs were washed and stained with anti-CD4-FITC, anti-CD25-PE (BD Biosciences, San Diego, CA, USA) and anti-FOXP3-APC (eBioscience, Inc.), and then threecolor flow cytometry analysis was performed. The positive $\left(\mathrm{CD} 4^{+} \mathrm{CD} 25^{+}\right)$cells were detected as Treg cells by analyzing at least 5000 PBMCs. Th1/Th2 cells were stimulated and stained with the Th1/Th2 cells test kit (BD Biosciences). The test used anti-CD3-PerCP-Cy5-5 and anti-CD8-PE-Cy7 to identify the Th cells. Th1 and Th2 cells were stained with anti-IFN $\gamma$-FITC and antiIL4-PE respectively.

\section{RNA isolation and real-time quantitative PCR}

Total RNA was isolated from PBMCs using TRIzol reagent (Ambion; Life Technologies). The FOXP3 mRNA expression was quantified by RT-PCR using 
an ABI Prism 7500 Sequence Detector (Applied Biosystems; Life Technologies). RT and PCR were performed (SYBR PrimeScript RT-PCR Kit; Takara Bio, Inc., Otsu, Shiga, Japan) using primer for FOXP3 designed as follows: 5'-TTCGAAGAGCCAGAGGACTT$3^{\prime}$ and $5^{\prime}$-GCTGCTCCAGAGACTGTACC-3'. The primer set for $\beta$-actin consisted of $5^{\prime}$-ATCTGCTGGAAGGTGGACAGCGA-3' and 5'-CCCAGCACAATGAAGATCAAGATCAT- $3^{\prime}$. The total reaction volume was $20 \mu \mathrm{l}$ and the PCR was programed as an initial incubation for $30 \mathrm{~s}$ at $95^{\circ} \mathrm{C}$ followed by 40 thermal cycles of $5 \mathrm{~s}$ at $95^{\circ} \mathrm{C}$ and $34 \mathrm{~s}$ at $60^{\circ} \mathrm{C}$. The relative quantity of FOXP 3 mRNA of GD PBMCs to normal PBMCs was calculated by using the following equation: $2^{-\Delta \Delta C_{\mathrm{t}}}$. All reactions were confirmed by at least one additional independent run.

\section{Functional analysis of Treg cells}

$\mathrm{CD} 4{ }^{+} \mathrm{CD} 25^{-} \mathrm{T}$ cells $\left(1 \times 10^{5}\right)$ were mixed with or without $\mathrm{CD} 4^{+} \mathrm{CD} 25^{+}$Treg cells $\left(1 \times 10^{4}\right)$ in the presence of anti-CD3 and anti-CD28 MABs. The cells were then cultured for $72 \mathrm{~h}$ in complete RPMI-1640 medium in 24-well plates. 5-(6)-Carboxyfluorescein diacetate N-succinimidyl ester (CFSE; Sigma-Aldrich) was added for cell labeling $15 \mathrm{~min}$ before cell proliferation analysis by flow cytometry. Treg cell function was analyzed using the proliferation rate of $\mathrm{CD} 4{ }^{+} \mathrm{CD} 25^{-} \mathrm{T}$ cells, according to the following formula: cell proliferation rate $(\%)=$ proliferation rate of $\mathrm{CD} 4{ }^{+} \mathrm{CD} 25^{-} \mathrm{T}$ cells co-cultured with $\mathrm{CD} 4{ }^{+} \mathrm{CD} 25^{+} \mathrm{T}$ cells/proliferation rate of $\mathrm{CD} 4^{+} \mathrm{CD} 25^{-} \mathrm{T}$ cells alone $\times 100 \%$.

\section{Statistical analysis}

All the experiments were run in triplicate. Statistical analysis was performed using SPSS 16.0 Software (SPSS, Inc., Chicago, IL, USA). Data are expressed as mean \pm s.E.M. The differences between two groups were analyzed using the two-tailed Student's $t$-test: a $P$ value $<0.05$ was considered significant.

\section{Results}

\section{Proportion of circulating $\mathrm{CD4}^{+} \mathrm{T}$ cell subsets and expression of FOXP3 mRNA in GD patients}

We comparatively studied the proportion of different $\mathrm{CD}^{+}{ }^{+} \mathrm{T}$ cell subsets in the PBMCs from GD patients and healthy controls by flow cytometry, as shown in Fig. 1A and $\mathrm{B}$. The percentage of $\mathrm{CD} 4{ }^{+} \mathrm{CD} 25^{+}$Treg cells in GD patients was significantly lower than that in healthy controls $(P<0.05)$, and a significantly higher proportion of Th1 cells was detected in patients with GD compared with healthy controls $(P<0.05)$. No significant difference was found in the proportion of Th2 cells between patients with GD and healthy controls $(P>0.05)$.
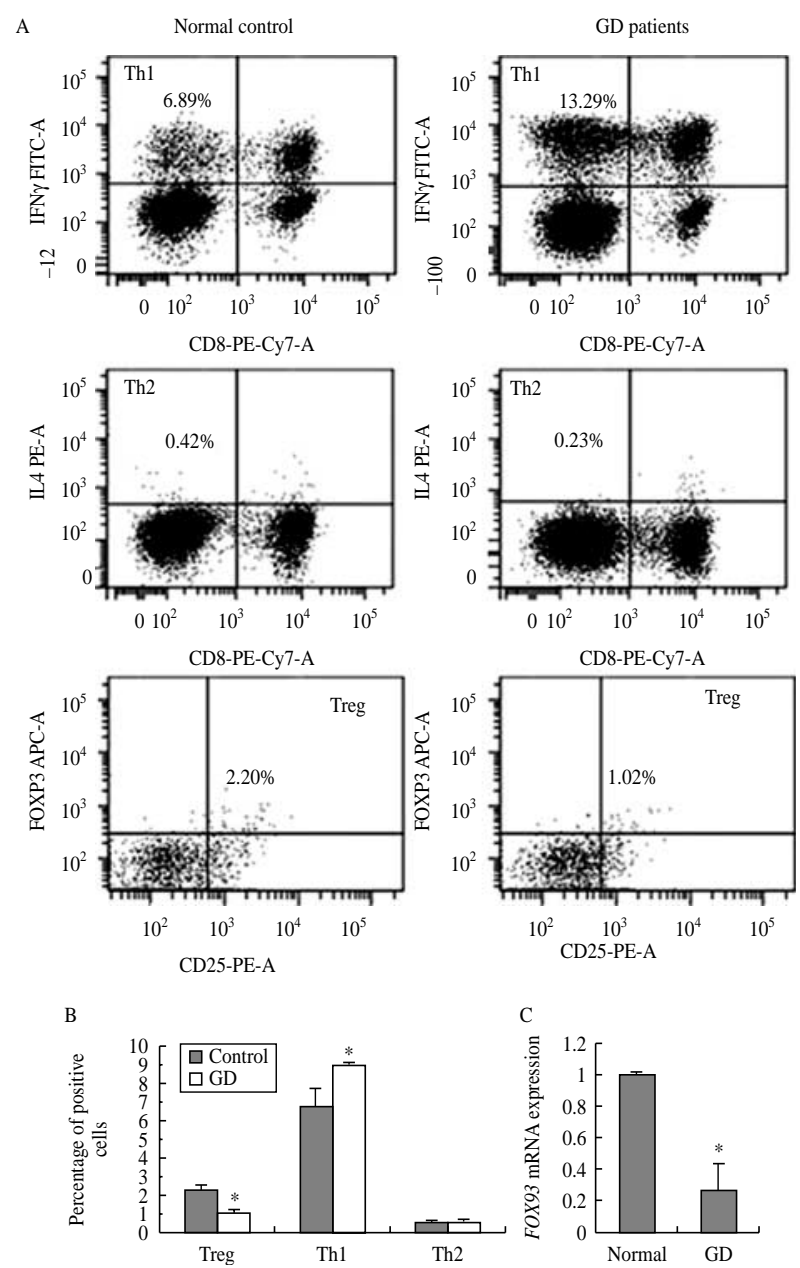

Figure 1 (A) Representative results showing the percentage of Th1, Th2, or Treg cells among PBMCs in patients with GD and healthy controls, as shown by flow cytometry. (B) The proportion of Th1, Th2, or Treg cells among PBMCs in GD patients and healthy controls. (C) The FOXP3 mRNA expression in GD patients and healthy controls. ${ }^{*} P<0.05$ for difference vs control using the two-tailed Student's $t$-test.

To corroborate the differences in Treg cell proportion between GD patients and healthy controls, we quantified FOXP3 mRNA expression in PBMCs by RT-PCR. The results showed that FOXP 3 mRNA expression of PBMCs was also lower in patients with GD than in healthy controls $(P<0.05$; Fig. $1 C)$.

\section{Treg cell function in patients with GD}

The function of $\mathrm{CD} 4^{+} \mathrm{CD} 25^{+}$Treg cells was evaluated by the proliferation rate of $\mathrm{CD} 4{ }^{+} \mathrm{CD} 25^{-} \mathrm{T}$ cells with flow cytometry. The results showed that the proliferation rates of $\mathrm{CD} 4{ }^{+} \mathrm{CD} 25^{-} \mathrm{T}$ cells in healthy controls and GD patients were $64.97 \%(60.1 / 92.5 \times 100 \%)$ and $88.21 \%$ $(74.8 / 84.8 \times 100 \%)$ respectively. According to this result, the suppressive function of Treg cells was lower in patients with GD than in healthy controls $(P<0.01$; Fig. 2). 
A
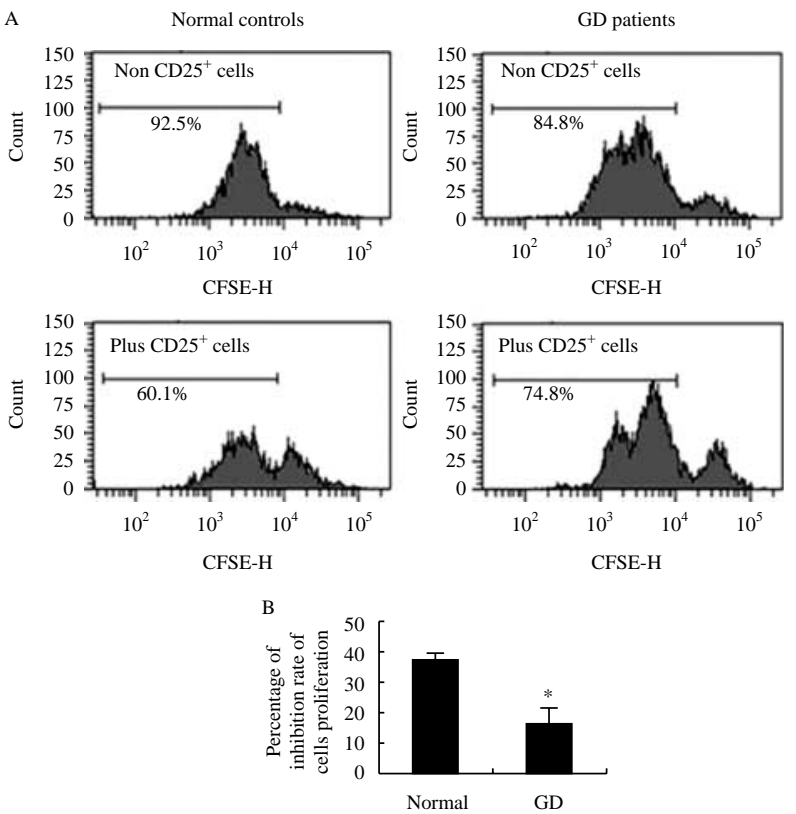

Figure 2 (A) Representative results showing the Treg cell function in GD patients and healthy controls, as shown by flow cytometry. (B) Treg cell function in GD patients and healthy controls, represented as the inhibition rate of $\mathrm{CD} 4^{+} \mathrm{CD} 25^{-}$T cells by Treg cells. ${ }^{*} P<0.01$ for difference vs control using the two-tailed Student's $t$-test.

\section{Effects of immunosuppressive agents on the proportion of circulating T-cell subsets}

We then evaluated the effects of DEX, CTX, and AZA on the proportion of circulating T-cell subsets. DEX, CTX, AZA, and blank control were co-cultured with PBMCs that were isolated from GD patients for $72 \mathrm{~h}$. The terminal concentrations of these immunosuppressive agents were all $10^{-5} \mathrm{mmol} / \mathrm{l}$. The dose of these drugs was determined by the results of the MTT assay. The MTT assay showed that higher concentrations of the drugs caused cell death. As shown in Fig. 3, the percentages of $\mathrm{CD}^{+}{ }^{+} \mathrm{CD} 25^{+}$Treg cells all decreased when the cells were treated with immunosuppressive agents (DEX, CTX, and AZA) compared with the control ( $P<0.01$ for each comparison), Th1 cells increased in the cells treated with CTX compared with the control $(P<0.05)$, whereas Th2 cells decreased in the cells treated with DEX compared with the control $(P<0.01)$.

\section{Changes in FOXP3 mRNA expression in PBMCs after treatment with immunosuppressive agents}

In order to confirm the effects of immunosuppressive agents on the quantity of Treg cells, we evaluated the FOXP3 gene expression by RT-PCR after treating the PBMCs with DEX, CTX, and AZA. As shown in Fig. 4, there was no significant difference in FOXP3 gene expression in the DEX- and CTX-treated PBMCs compared with the control. However, FOXP3 mRNA expression decreased in the cells treated with AZA compared with the control $(P<0.05)$.

\section{Function of Treg cells affected by immuno- suppressive agents in patients with GD}

When Treg cells and $\mathrm{CD} 4^{+} \mathrm{CD} 25^{-} \mathrm{T}$ cells (mixed at a 1:10 ratio) were co-cultured with immunosuppressive agents for $72 \mathrm{~h}$, the suppressive function of Treg cells was improved by DEX in patients with GD compared with the control $(P<0.01)$. However, there were no significant changes in the functions of Treg cells after the cells were co-cultured with CTX and AZA in patients with GD (see Fig. 5A). Moreover, we observed that CTX impaired the function of Treg cells in healthy subjects, but there were no significant effects of DEX and AZA on the functions of Treg cells in healthy subjects (see Fig. 5B).

\section{Discussion}

This study confirms the findings of previous studies $(3,18,19)$ that found a lower proportion of Treg cells in the peripheral blood of GD patients. The results are confirmed by quantified FOXP 3 mRNA expression, identified as the most specific marker for active Treg cells. Moreover, Treg cell function was impaired in patients with GD in this study. Although the role of Treg cells in the pathogenesis of GD in humans is not fully understood, depletion of Treg cells could cause C57BL/ 6 mice to develop GD $(1,2)$. A decrease in Treg cell function might be a crucial factor in the pathogenesis of GD. Accordingly, an increase in the proportion or an improvement in the function of Treg cells might help in the remission of GD. Although the proportion of Treg cells did not increase, the suppressive function of Treg cells improved after treatment with DEX in this study. Considering the results of our previous study (13) along with the results of this study, we have reason to believe that DEX has some beneficial effects in the treatment of patients with GD, and the role of DEX on GD patients might be, at least partially, to regulate Treg cells.

The exact reason for Treg cell dysfunction in GD patients remains poorly understood. Among different

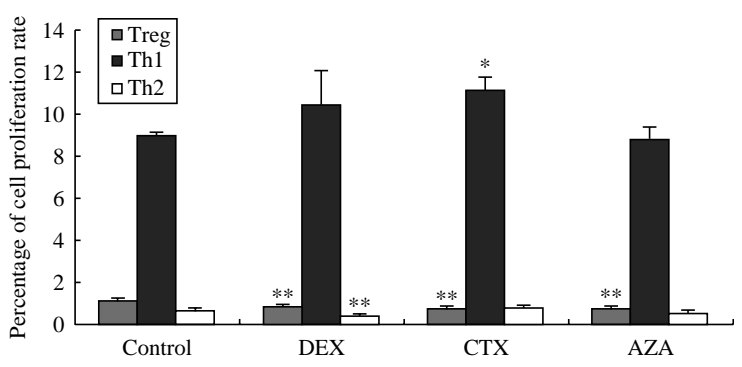

Figure $\mathbf{3} \mathrm{Immunosuppressive} \mathrm{agents} \mathrm{affecting} \mathrm{the} \mathrm{proportion} \mathrm{of}$ T-cell subsets in GD patients. ${ }^{*} P<0.05$ and ${ }^{* \star} P<0.01$ for difference vs control using two-tailed Student's $t$-test. 


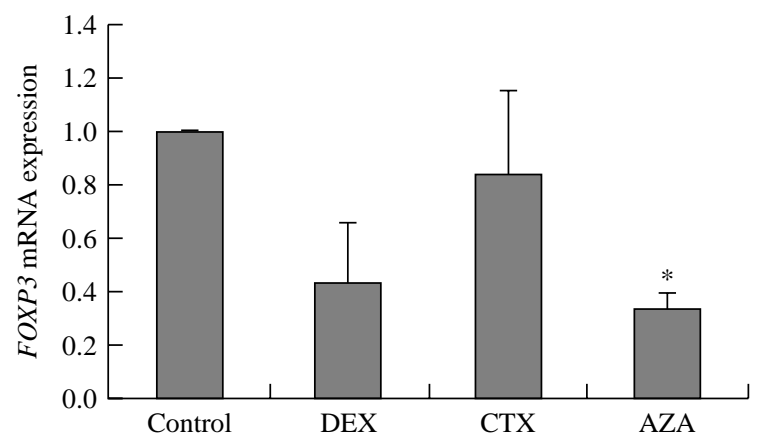

Figure 4 Effects of DEX, CTX, and AZA on FOXP3 mRNA expression in PBMCs. ${ }^{*} P<0.05$ for difference vs control using the two-tailed Student's $t$-test.

professional antigen-presenting cells, it is now widely accepted that dendritic cells (DCs) are the most potent, involving both the primary and secondary immune responses (20). Mao et al. (3) found that DCs derived from untreated GD patients through plasmacytoid DC polarization impaired the regulatory capacity of Treg cells.

The proportion of Treg cells in PBMCs significantly decreased with treatment from all of the immunosuppressive agents (DEX, CTX, and AZA); however, FOXP3 mRNA expression decreased slightly in this study. Only AZA treatment significantly reduced the FOXP 3 mRNA expression. This discrepancy might be attributed to the existence of other PBMCs expressing FOXP3, e.g. B-cells and NK cells $(21,22)$. These cells were included in the mRNA detection of PBMCs, and can be identified by flow cytometry in the Treg cell proportion test. The decrease in the proportion of Treg cells in this study might be due to the immunosuppressive agents inducing apoptosis in T-cells $(23,24)$. However, some in vivo studies have produced opposite results $(16,17,25)$. Giorgini et al. (26) reported that Treg cells were resistant to the inhibition induced by DEX but not by rapamycin.

In this study, we also observed the effects of CTX and AZA on the function of Treg. The results suggested that CTX and AZA did not have any effect on Treg cell function, so CTX and AZA might not be suitable for treating GD.

Th lymphocytes consist of two subpopulations, Th1 and Th2, regulated by Treg cells via cell-to-cell contact or the release of suppressive cytokines, such as transforming growth factor $\beta$ or IL10 (5). The balance between Th1 and Th2 lymphocytes may determine the outcome of autoimmune diseases. Recent studies have suggested that both Th1 and Th2 cells participate in the pathogenesis of GD, and the roles of Th1 and Th2 on the pathogenesis of GD are diverse at different phases of GD (9). The development of GD is related to the production of antithyroid antibodies, which suggests the importance of Th2 cells in the pathogenesis of GD. Following the improvement in Treg cell function, the proportion of Th2 cells decreased with DEX treatment in this study. Although GD's classification as a typical Th1-dominant disease is up for debate, some studies have suggested that Th1 cells play a role in the induction of GD $(9,27)$. In this study, we found an increase in the proportion of Th1 cells in GD patients, which corresponds to the result of other reports $(9,28)$. After DEX treatment, Th1 cells were not affected. One possible explanation is that the proportion of Treg cells was reduced by the DEX treatment. Another possible explanation is the patients whom we selected in this study. Moreover, the balance between Th1 and Th2 cells plays an important role in the outcome of GD, and the regulation of this balance by Treg cells is much more complex.

In summary, this study shows that DEX could effectively improve the function of Treg cells and set up a new balance of Th1 and Th2 cells in GD patients, which might be helpful to further understand the immune mechanism of the intrathyroid injection of DEX in the treatment of GD and facilitate the potential use of this therapy. Finally, we consider it necessary to perform additional studies, especially in vivo studies, to fully elucidate the complex role of Treg cells and the balance of Th1 and Th2 cells in the treatment of GD with immunosuppressive agents.

A

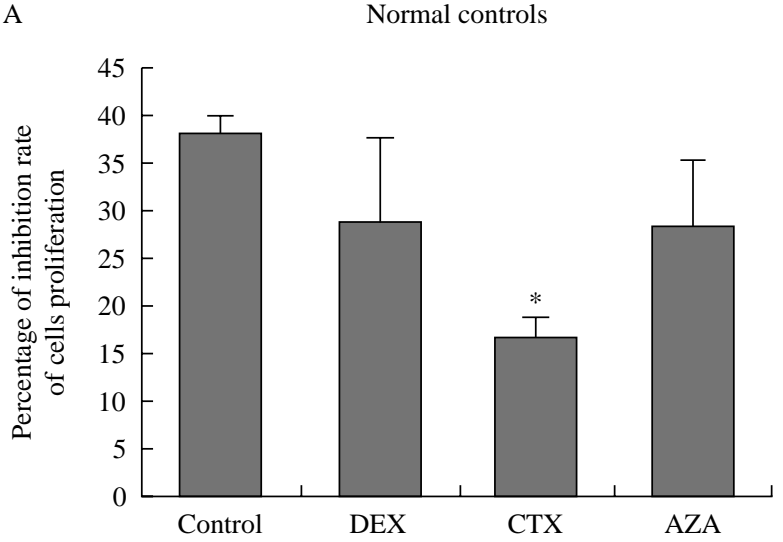

B

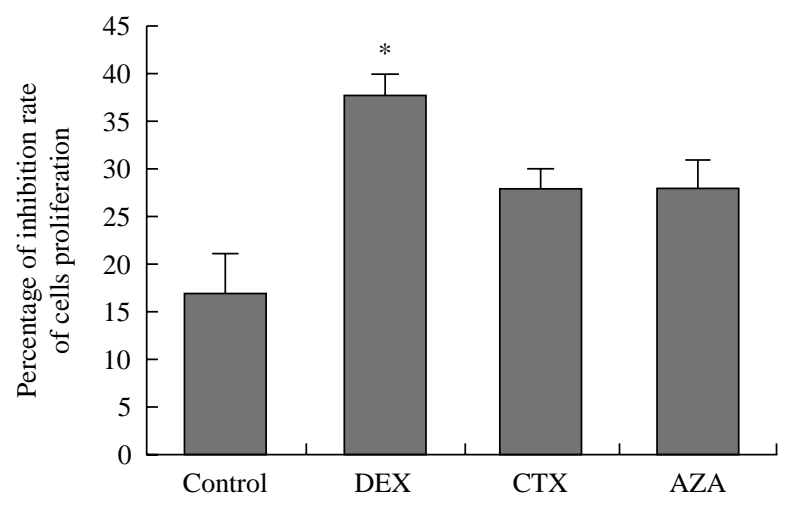

Figure 5 Effects of immunosuppressive agents on Treg cell function in (A) normal controls and (B) GD patients. ${ }^{*} P<0.01$ for difference vs control using the two-tailed Student's $t$-test. 


\section{Declaration of interest}

The authors declare that there is no conflict of interest that could be perceived as prejudicing the impartiality of the research reported.

\section{Funding}

This research did not receive any specific grant from any funding agency in the public, commercial or not-for-profit sector. It was supported by grants from the Health Department of Jiangsu Province (H200829).

\section{References}

1 Nagayama Y, Horie I, Saitoh O, Nakahara M \& Abiru N. $\mathrm{CD} 4{ }^{+} \mathrm{CD} 25^{+}$naturally occurring regulatory $\mathrm{T}$ cells and not lymphopenia play a role in the pathogenesis of iodide-induced autoimmune thyroiditis in NOD-H2h4 mice. Journal of Autoimmunity 200729 195-202. (doi:10.1016/j.jaut.2007.07.008)

2 Saitoh 0 \& Nagayama Y. Regulation of Graves' hyperthyroidism with naturally occurring $\mathrm{CD} 4{ }^{+} \mathrm{CD} 25^{+}$regulatory $\mathrm{T}$ cells in a mouse model. Endocrinology 2006147 2417-2422. (doi:10. 1210/en.2005-1024)

3 Mao C, Wang S, Xiao Y, Xu J, Jiang Q, Jin M, Jiang X, Guo H, Ning G \& Zhang Y. Impairment of regulatory capacity of $\mathrm{CD} 4^{+} \mathrm{CD} 25^{+}$ regulatory $\mathrm{T}$ cells mediated by dendritic cell polarization and hyperthyroidism in Graves' disease. Journal of Immunology 2011 186 4734-4743. (doi:10.4049/jimmunol.0904135)

4 McLachlan SM, Nagayama Y, Pichurin PN. Mizutori Y, Chen CR, Misharin A, Aliesky HA \& Rapoport B. The link between Graves' disease and Hashimoto's thyroiditis: a role for regulatory T cells. Endocrinology 2007148 5724-5733. (doi:10.1210/en.2007-1024)

5 Romagnani S. Regulatory T cells: which role in the pathogenesis and treatment of allergic disorders? Allergy 2006 61 3-14. (doi:10.1111/j.1398-9995.2006.01005.x)

6 Mosmann TR, Cherwinski H, Bond MW, Giedlin MA \& Coffman RL. Two types of murine helper T cell clone. I. Definition according to profiles of lymphokine activities and secreted proteins. Journal of Immunology $19861362348-2357$.

7 Mosmann TR \& Coffman RL. TH1 and TH2 cells: different patterns of lymphokine secretion lead to different functional properties. Annual Review of Immunology 19897 145-173. (doi:10.1146/ annurev.iy.07.040189.001045)

8 Nicholson LB \& Kuchroo VK. Manipulation of the Th1/Th2 balance in autoimmune disease. Current Opinion in Immunology 19968 837-842. (doi:10.1016/S0952-7915(96)80013-6)

9 Inukai Y, Momobayashi A, Sugawara N \& Aso Y. Changes in expression of T-helper (Th) 1- and Th2-associated chemokine receptors on peripheral blood lymphocytes and plasma concentrations of their ligands, interferon-inducible protein-10 and thymus and activation-regulated chemokine, after antithyroid drug administration in hyperthyroid patients with Graves' disease. European Journal of Endocrinology 2007156 623-630. (doi:10. 1530/EJE-07-0019)

10 Abraham P, Avenell A, Park CM, Watson WA \& Bevan JS. A systematic review of drug therapy for Graves' hyperthyroidism. European Journal of Endocrinology 2005153 489-498. (doi:10. 1530/eje.1.01993)

11 Weetman AP. Graves' disease. New England Journal of Medicine 2000343 1236-1248. (doi:10.1056/NEJM200010263431707)

12 Nedrebo BG, Holm PI, Uhlving S, Sorheim JI, Skeie S, Eide GE, Husebye ES, Lien EA \& Aanderud S. Graves' disease: drug regimens and predictors of outcome. European Journal of Endocrinology 2002 147 583-589. (doi:10.1530/eje.0.1470583)

13 Mao XM, Li HQ, Li Q, Li DM, Xie XJ, Yin GP, Zhang P, Xu XH, Wu JD, Chen SW \& Wang SK. Prevention of relapse of Graves' disease by treatment with an intrathyroid injection of dexamethasone. Journal of Clinical Endocrinology and Metabolism 200994 4984-4991. (doi:10.1210/jc.2009-1252)

14 Wiersinga WM, Smit T, Schuster-Uittenhoeve AL, van der Gaag R \& Koornneef L. Therapeutic outcome of prednisone medication and of orbital irradiation in patients with Graves' ophthalmopathy. Ophthalmologica 1988197 75-84. (doi:10.1159/000309924)

15 Lacka K, Manuszewska E, Korczowska I \& Lacki JK. The effect of methylprednisolone pulse treatment on cytokine network in Graves ophthalmopathy. Current Eye Research 200732 291-297. (doi:10. 1080/02713680601186698)

16 Suárez A, López P, Gómez J, Gutiérrez C \& Suárez A. Enrichment of $\mathrm{CD}^{+} \mathrm{CD} 25$ high $\mathrm{T}$ cell population in patients with systemic lupus erythematosus treated with glucocorticoids. Annals of the Rheumatic Diseases 200665 1512-1517. (doi:10.1136/ard.2005.049924)

17 Ling Y, Cao X, Yu Z \& Ruan C. Circulating dendritic cells subsets and $\mathrm{CD} 4{ }^{+} \mathrm{Foxp}^{+}{ }^{+}$regulatory T cells in adult patients with chronic ITP before and after treatment with high-dose dexamethasome. European Journal of Haematology $2007 \mathbf{7 9}$ 310-316. (doi:10. $1111 /$ j.1600-0609.2007.00917.x)

18 Marazuela M, García-López MA, Figueroa-Vega N, de la Fuente H, Alvarado-Sánchez B, Monsiváis-Urenda A, Sánchez-Madrid F \& González-Amaro R. Regulatory T cells in human autoimmune thyroid disease. Journal of Clinical Endocrinology and Metabolism 200691 3639-3646. (doi:10.1210/jc.2005-2337)

19 Dang S \& Shi BY. Variation of CD4 CD25 regulatory T cells in patients with Graves' disease. Chinese Journal of Endocrinology and Metabolism 200723 253-256.

20 Mellman I \& Steinman RM. Dendritic cells: specialized and regulated antigen processing machines. Cell 2001106 255-258. (doi:10.1016/S0092-8674(01)00449-4)

21 Noh J, Choi WS, Noh G \& Lee JH. Presence of Foxp3-expressing $\mathrm{CD} 19(+) \mathrm{CD} 5(+) \mathrm{B}$ cells in human peripheral blood mononuclear cells: human CD19(+)CD5(+)Foxp3(+) regulatory B cell (Breg). Immune Network 201010 247-249. (doi:10.4110/in.2010.10.6. 247)

22 Engelmann P, Farkas K, Kis J, Richman G, Zhang Z, Liew CW, Borowiec M, Niewczas MA, Jalahej H \& Orbán T. Characterization of human invariant natural killer Tcells expressing FoxP3. International Immunology 201123 473-484. (doi:10.1093/intimm/dxr040)

23 Pallardy M \& Biola A. Induction of apoptosis in lymphocytes by glucocorticoids: between physiology and pharmacology. Comptes Rendus des Séances de la Société de Biologie et de Ses Filiales 1998 192 1051-1063.

24 Grbović L \& Radenković M. Therapeutic use of glucocorticoids and immunosuppressive agents. Srpski Arhiv za Celokupno Lekarstvo 2005133 (Suppl 1) 67-73.

25 Kang Y, Xu L, Wang B, Chen A \& Zheng G. Cutting edge: immunosuppressant as adjuvant for tolerogenic immunization. Journal of Immunology $2008 \mathbf{1 8 0} 5172-5176$.

26 Giorgini A \& Noble A. Blockade of chronic graft-versus-host disease by alloantigen-induced $\mathrm{CD} 4{ }^{+} \mathrm{CD} 25^{+} \mathrm{Foxp} 3^{+}$regulatory $\mathrm{T}$ cells in nonlymphopenic hosts. Journal of Leukocyte Biology 2007 82 1053-1061. (doi:10.1189/jlb.0407227)

27 Ward LS \& Fernandes GA. Serum cytokine levels in autoimmune and non-autoimmune hyperthyroid states. Brazilian Journal of Medical and Biological Research 200033 65-69. (doi:10.1590/ S0100-879X2000000100009)

28 Romagnani P, Rotondi M, Lazzeri E, Lasagni L, Francalanci M, Buonamano A, Milani S, Vitti P, Chiovato L, Tonacchera M, Bellastella A \& Serio M. Expression of IP-10/CXCL10 and MIG/CXCL9 in the thyroid and increased levels of IP-10/CXCL10 in the serum of patients with recent-onset Graves' disease. American Journal of Pathology 2002161 195-206. (doi:10. 1016/S0002-9440(10)64171-5)

Received 9 October 2011

Revised version received 22 December 2011

Accepted 4 January 2012 